\title{
New Assessment of the Analysis of Wastewater Quality on a Wastewater Treatment Plant Using the RAPS Method
}

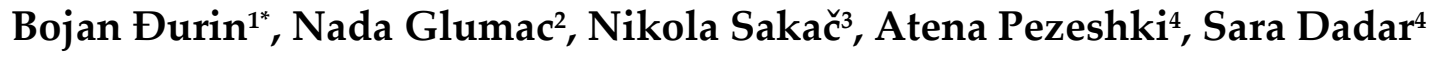 \\ Received: date; Accepted: date; Published: date \\ Academic Editor: name \\ 1 University North, Department of Civil Engineering, Varaždin, Croatia; bojan.durin@unin.hr \\ 2 Međimurske Vode, Čakovec, Croatia; nada.glumac@medjimurske-vode.hr \\ 3 University of Zagreb, Faculty of Geotehnical Engineering, Varaždin, Croatia; nikola.sakac@gfv.unizg.hr \\ 4 Department of Water Science and Engineering, Faculty of Agriculture, Ferdowsi University of Mashhad, \\ Mashhad, Iran; atena.pezeshki@mail.um.ac.ir, sara.dadar@mail.um.ac.ir
}

\begin{abstract}
Water is an important factor in human health and an essential ingredient of living organisms. The increase of population and living standard has led to the increased water consumption consequently causing the increase of wastewaters, as well as bigger quality impairment. Wastewater treatment of the public mixed drainage system of the city of Čakovec (Croatia) and surrounding suburban settlements is carried out by mechanical and biological procedures, with the final treatment of separated sludge. In this paper we analyzed the input and output values of annual time series for chemical oxygen demand (COD) on the wastewater treatment plant in 2015 using the RAPS method (Rescaled Adjusted Partial Sums). The results showed that the input series contained more pronounced subseries with respect to their mean values and trends of increase and decrease, respectively. When comparing the input and output subseries, the output subseries do not oscillate to a large extent given that they express the output quality of wastewater. A significant reduction in the output values of the indicators determines the quality treatment of incoming wastewater.
\end{abstract}

Keywords: waste water; treatment plant; quality; time series; RAPS

\section{Introduction}

Water is one of a basic condition for maintaining life, which is why it is important to determine water needs and uses. The development of industry and technology contributes to a higher standard and life quality, which is especially reflected in the large increase in water consumption. The water is easily accessible to all consumer groups through the construction of water supply systems. This results in large quantities of waste (used) water of significantly changed quality compared to the original [1]. Wastewater treatment is a technological process that is carried out on treatment plants. The choice of treatment procedures, and the level of water purification, depends primarily on the quantity and composition of wastewater (type of wastewater), as well as on the required water quality at the discharge site [2]. The Wastewater Treatment Plant (WWTP) of the city of Čakovec is located at the southeastern entrance to the Čakovec, Croatia, Figures 1 [3, 4]. 


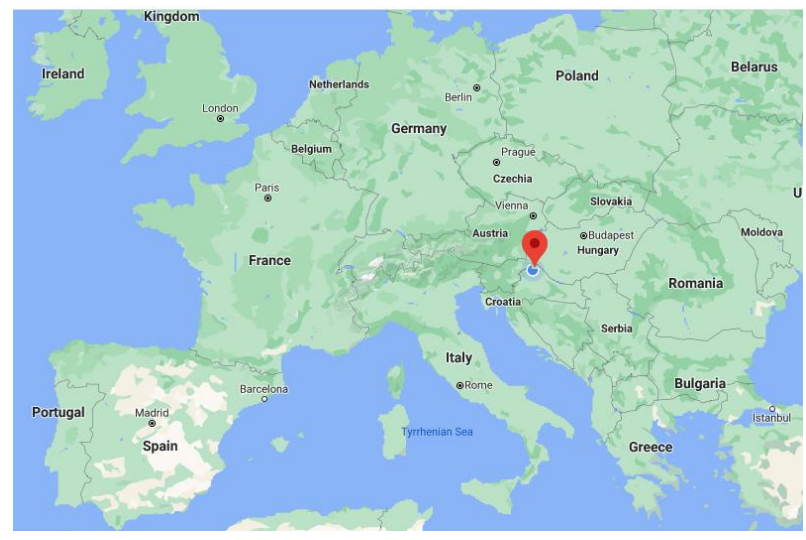

(a)

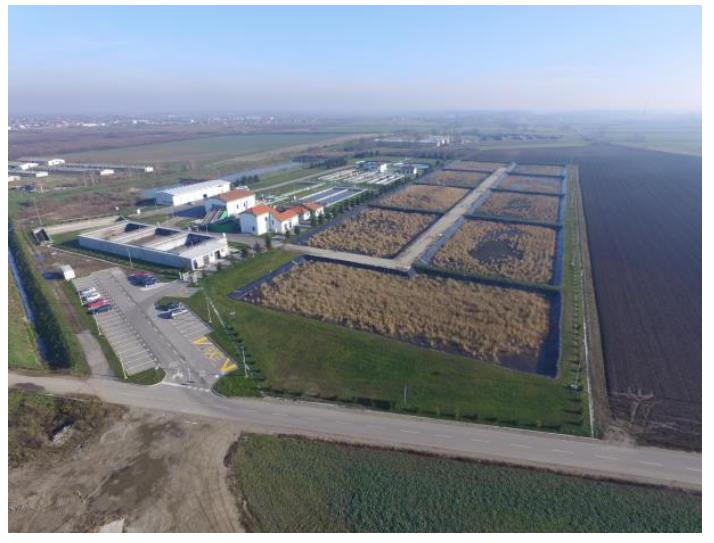

(b)

Figure 1. (a) Location of the wastewater treatment plant Čakovec; (b) Closer view on the wastewater treatment plant Čakovec

WWTP and facilities (rain overflows, rain retention basins, and transport collectors) were constructed for Čakovec and suburbs with a capacity of 91,000 ES. Wastewater treatment of the public drainage system of Čakovec and suburban settlements, which is of a mixed type, is carried out by mechanical and biological procedures with the final treatment of the separated sludge. Impacts on inlet wastewater quality can be natural and anthropogenic. Natural influences that affect the quality of wastewater are temperature, precipitation and evaporation. Human activity belongs to the anthropogenic factor that significantly affects negatively the quality of wastewater.

The aim of this paper is to use the Rescaled Adjusted Partial Sums (RAPS) method to determine whether the series of indicators of wastewater quality of WWTP in Čakovec contain characteristic sub-series with respect to their mean values and trends of increase or decrease in value.

\section{Methods}

RAPS method is used for the analysis of input and output values of the Chemical Oxygen Demand (COD) for II Level of treatment, according to the Croatian legislation [5] for the time serie during year 2015.

The RAPS method is based on the analysis of the time distribution of the outflow of the summary deviation curve. A visual graphical display based on RAPS transformation is convenient because it allows overcoming small systematic and random changes, errors and variability in the analyzed time series. The graphical representation of the RAPS method indicates the existence of several subseries that have similar characteristics, a larger number of trends, sudden jumps and falls in values, unregulated fluctuations, etc. [6]. The expression used for RAPS calculation is defined as:

$$
R A P S_{k}=\sum_{t=1}^{k} \frac{Y_{t}-\bar{Y}}{S_{y}},
$$

$Y_{t}$ is value of the analyzed member (parameter) of the considered time serie;

$\bar{Y}$ is average value of the considered time serie;

$S_{y}$ is standard deviation of the considered time serie;

$n$ is number of members of the considered time serie;

$k=1,2, \ldots, n$ is counter during sumation $[7,8]$. 
The graphical representation of the $R A P S_{k}$ value over the time indicates the existence of regularity in the fluctuations of the analyzed parameter $Y_{t}$, which in this case represents the value of a certain indicator of wastewater quality. Once the existence (or non-existence) of a subseries within a given serie is determined, the further procedure is to determine the linear trend of that subseries and, if necessary, statistical processing, i.e. calculation of basic statistical parameters of the given (original) serie, such as mean value, standard deviation, range, maximum and minimum value, and similar [7, $8]$.

The RAPS method is applied worldwide, as in following examples. In particular, RAPS is commonly used most in the analysis of hydrological and meteorological indicators. Bonacci in his work from 2010 uses the RAPS method in the analysis of series of mean annual air temperatures, measured at 26 meteorological stations in Croatia [7]. In [9], RAPS was used to determine the mean daily flow characteristics of the Sacramento River in California, USA. In [10], RAPS was applied to the analysis of the dependence of annual sediment volumes and flow of rivers in China, as well as annual total precipitation volumes in order to explain and define the mutual influences and dependencies of these quantities.

In [11], RAPS was used to determine the impact of climate change on limestone deposits in the Krka River Basin. The values of RAPS were determined by the average daily air temperature, the total amount of precipitation and the average daily water flow, i.e. the analysis of these indicators was performed. Bonacci and Andrić apply RAPS to determine the regime of karst water flow in the Lika and Gacka river basins [12]. Tadić uses the RAPS method in the analysis of trends in total daily precipitation in assessing the possibility of irrigation in the Osijek-Baranja County [13].

After reviewing the available bibliographic units related to the analysis of time series in which the RAPS method is used, it was found that this method has never been used in the world on the example of the analysis of wastewater quality indicators. Exception is research of the group of authors with leading of the first author Đurin in the [14-17], where this research was started, and now is an intention to extend research with domicile and international collaborators.

\section{Results and discussion}

Figures 2 to 7 show the total input and output values of COD for year 2015 at the WWTP in the city of Čakovec, where the RAPS method was applied to the given serie.

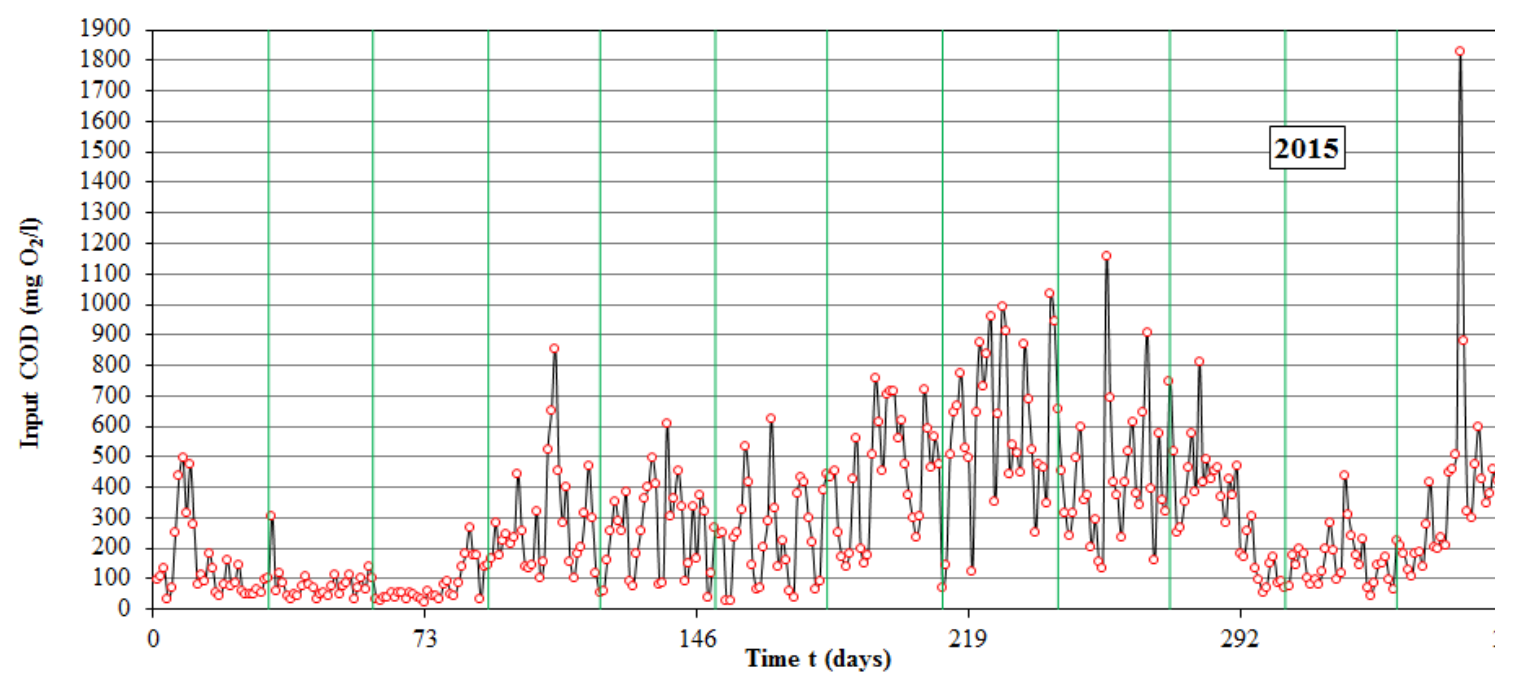

Figure 2. Input of COD for year 2015 


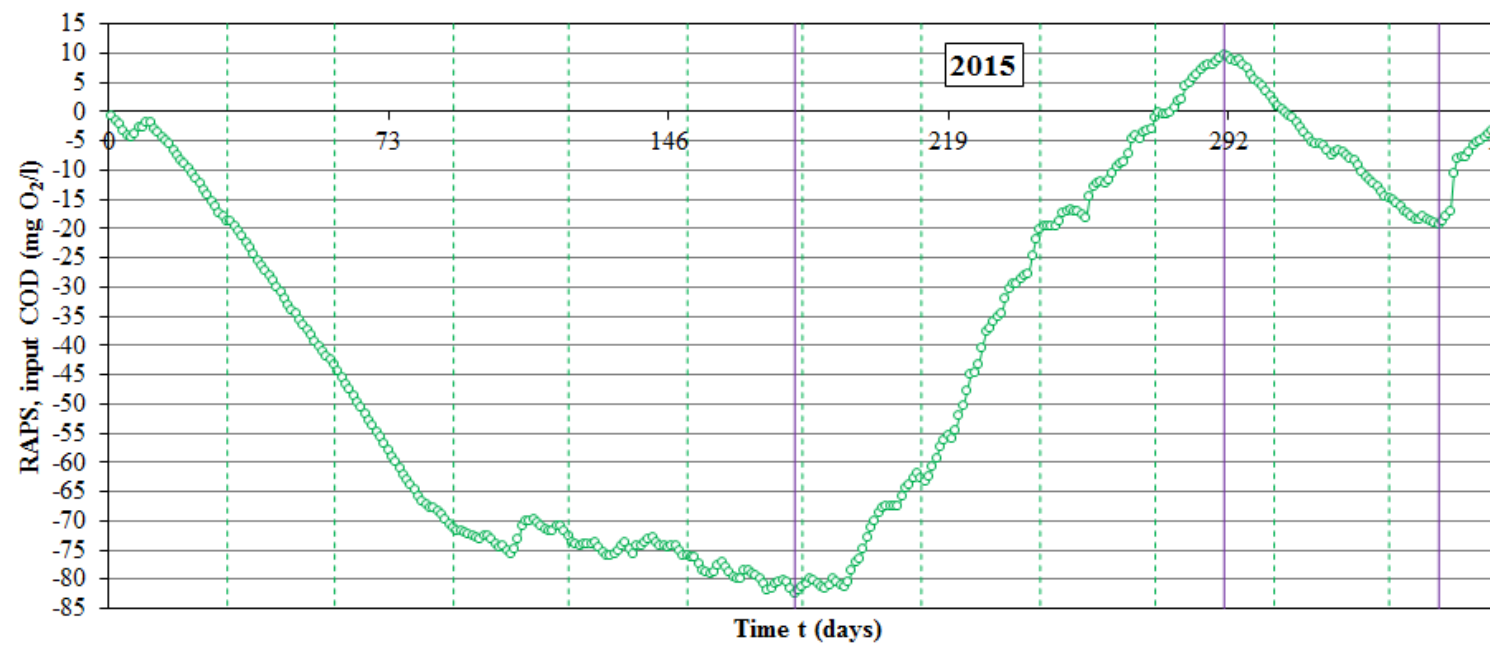

Figure 3. RAPS of the input COD for year 2015

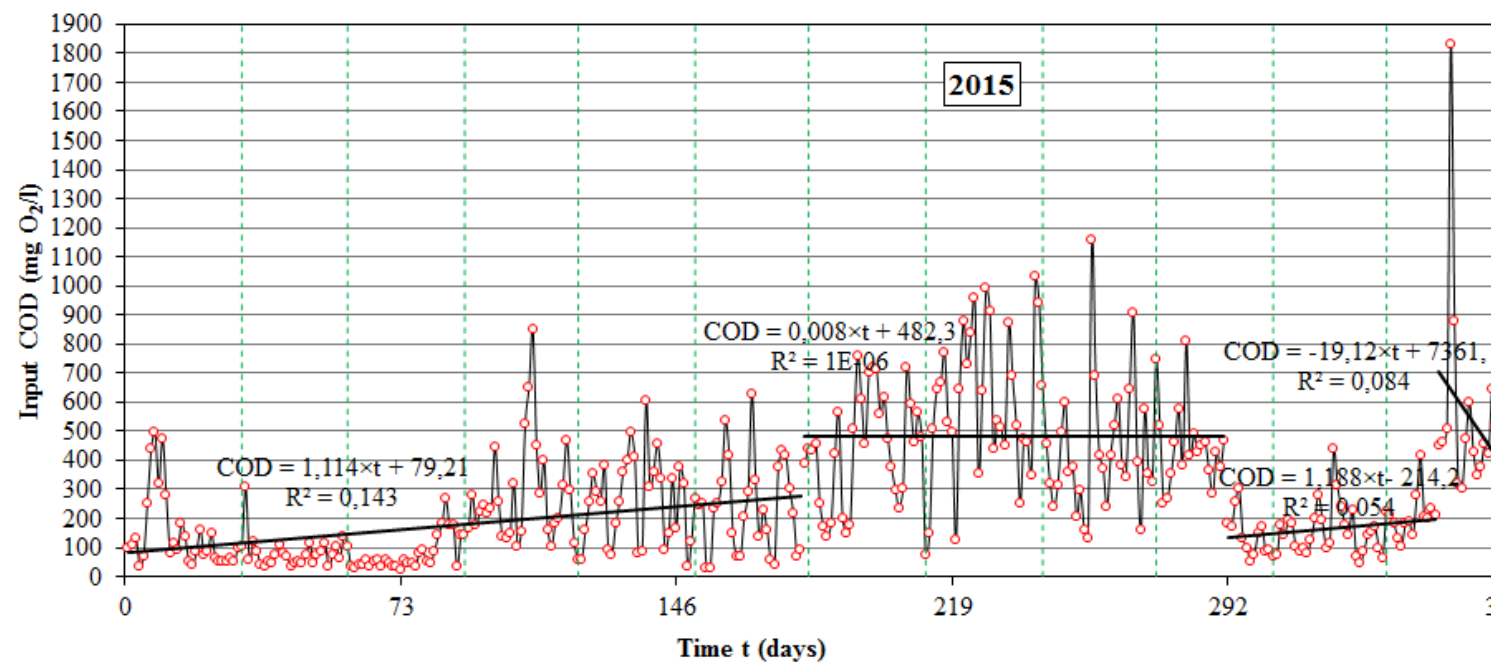

Figure 4. Subseries of the input COD for the year 2015

The values of input indicators of wastewater quality for 2015 are in second half of the year above the value of the Maximum allowed value (MAV), which is $700 \mathrm{mg} \mathrm{O}_{2} / 1$ for the COD [5]. Based on the performed analysis, it can be seen that the highest measured value of the coefficient of determination $R^{2}$ of an input serie is equal to 0.1439 , while the lowest calculated value of $R^{2}$ is $10^{-6}$. In both cases, there are insignificant. Growing trends of all subseries are observed, but given the negligible values of $R^{2}$, this has no argumentative significance.

Figures 5 to 7 show the total output values of the output indicators of the COD for 2015, also with the application of RAPS. 


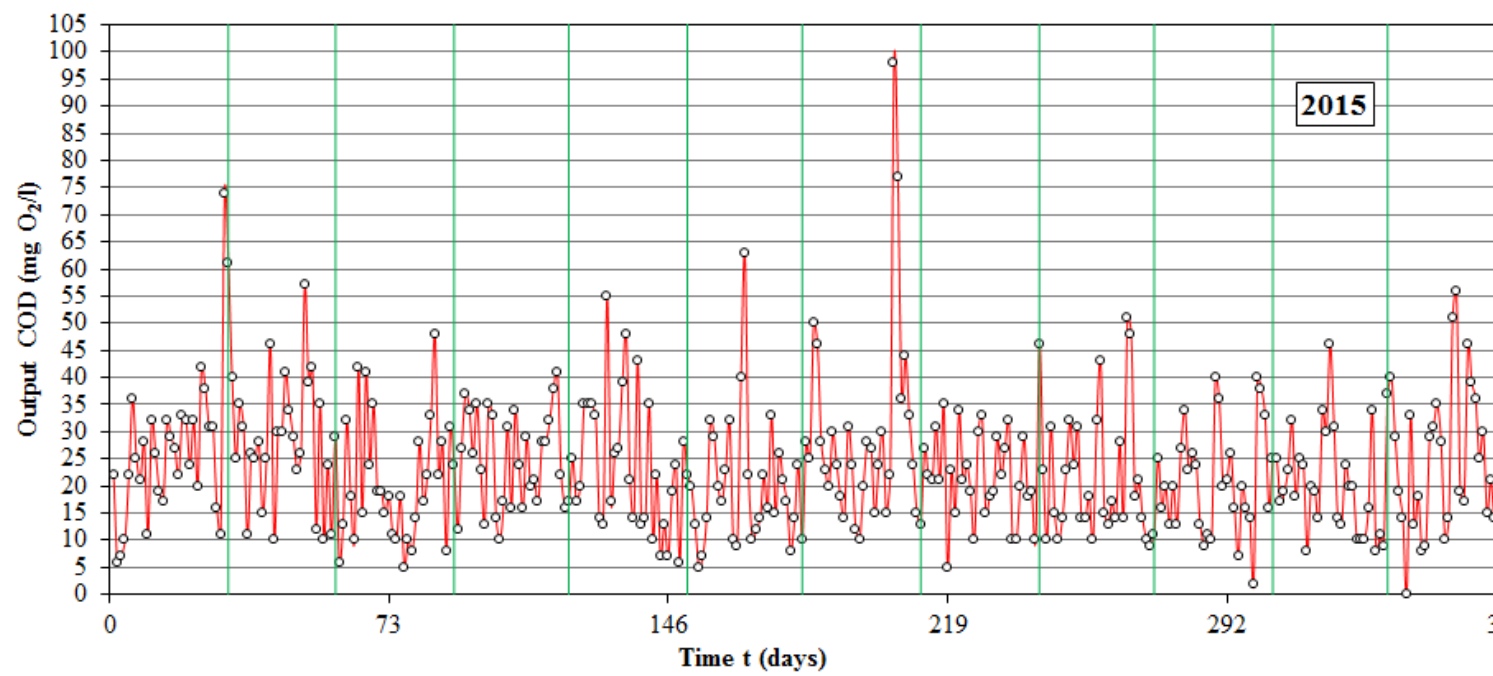

Figure 5. Output of COD for year 2015

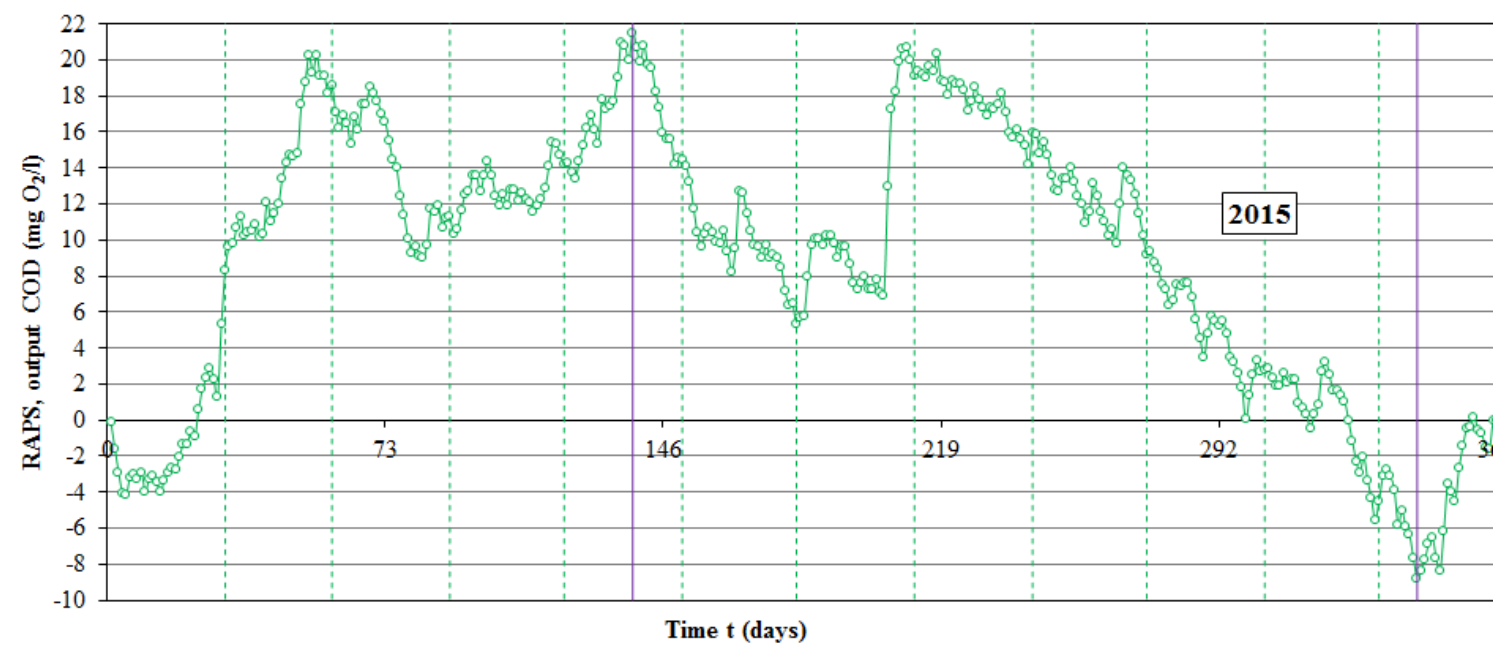

Figure 6. RAPS of the output COD for year 2015

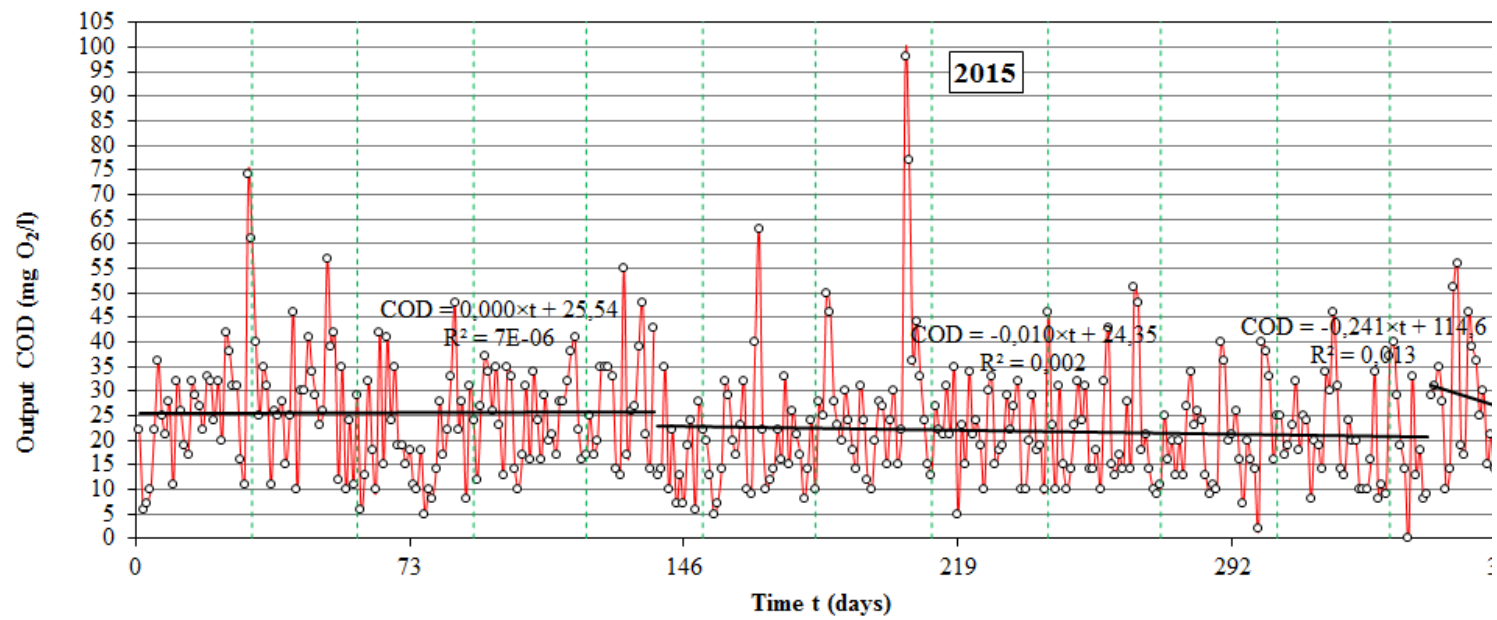

Figure 7. Subseries of the output COD for the year 2015

Declining trends of output subseries are observed, but given the negligible values of $R^{2}$, this has no argumentative significance, just as with input subsequences. 
Accordingly to the explanations and analysis at the laboratory in WWTP Čakovec, the output values of COD in 2015 did not exceed the permitted limit of $125 \mathrm{mg} / \mathrm{l}$ according to the MAV [5]. Biological treatment efficiencies, expressed as a percentage reduction in COD values deviated in the first quarter of the year is a result of changes in COD inputs (reductions), due to the inflow of large amounts of precipitation. In addition to this, there is certainly industrial water that is discharged into the public drainage system without prior treatment. Equally important is the quality of the sewer system, i.e. its water tightness, especially in those parts where the old concrete sewer is. Since the set output values are preserved and in accordance with regulations, these deviations are not significant. All deviations from the efficiency of COD reductions are due to poorly loaded water. In the conditions of inflow of very dilute wastewater, it is not biologically possible to achieve the required treatment efficiencies.

\section{Conclusion}

RAPS provides the ability to analyze that part of the time series that is problematic, while the trend of the entire time series does not allow this. In most cases, trends do not indicate or warn of a possible problem that occurs in a certain part of the time series. This enables faster and more accurate analysis, focusing on the real problem as well as faster reaction in order to eliminate it, which is extremely important in every branch of human activity, and thus in wastewater treatment. The RAPS method can significantly help in monitoring the operation of WWTPs, and also in the design of such devices, since the simplest procedures used today, namely data display and trend analysis, cannot give such a picture of the problem as it provides RAPS method.

Further research will include analysis for the longer time period, comparison with the time series of the hydraulical load, precipitation and insolation, as well as extension for the other indicators of the waste water quality, i.e. Biochemical Oxygen Demand during 5 days, Suspended Solids, and all others.

Author Contributions: B.Đ. and NG. conceived and designed the experiments; B.Đ., N.G. and N.S. performed the experiments; N.G. A.P. and S.D. analyzed the data; B.Đ., N.S., A.P. and S.D. contributed analysis tools; B.Đ. ,N.S., A.P. and S.D. wrote the paper."

Conflicts of Interest: The authors declare no conflict of interest.

\section{Abbreviations}

The following abbreviations are used in this manuscript:

WWTP: Wastewater Treatment Plant

COD: Chemical Oxygen Demand

MAV: Maximum allowed value

\section{References}

1. Tušar, Božena. Ispuštanje i pročišćavanje otpadne vode (original on Croatian; Wastewater discharge and treatment), Croatiaknjiga: Zagreb, Croatia, 2004; pp. 250.

2. Tušar, Božena. Pročišćavanje otpadnih voda (original on Croatian; Wastewater treatment), Kigen: Zagreb, Croatia, 2006; pp. 411.

3. Google maps. Available online: https://www.google.com/maps/place/\%C4\%8Cakovec/@44.4287764,1.3040555,4.75z/data=!4m5!3m4!1s0x4 768ada5b7bfc8e1:0x459315b89fe1d5!8m2!3d46.3897383!4d16.4379653?hl=en, (accessed on 25.10.2020.).

4. Međimurske Vode: Available online: http://medjimurske-vode.hr/wpcms/wpcontent/uploads/2018/02/DJI_0116.jpg, (accessed 02.11.2020.).

5. Narodne Novine. Pravilnik o graničnim vrijednostima emisija otpadnih voda (original on Croatian; Ordinance on limit values for wastewater emissions), No 66, 2020, Zagreb, Croatia. 
6. Rao, A.R.; Hamed, K.H.; Huey-Long, C. Nonstationarities in Hydrologic and Environmental Time Series. Springer: Switzerland, 2003; pp. 365.

7. Bonacci, O. Analiza nizova srednje godišnje temperature zraka u Hrvatskoj (original on Croatian; Analysis of mean annual air temperature series in Croatia). Građevinar 2010, 62 (9), pp. 781-791).

8. Machiwal, D., Jha, M.K. Hydrologic Time Series Analysis, Theory, and Practice. Springer/Capital Publishing Company, Germany/New Delhi, India, 2012, pp. 303.

9. Marlyn L. S. Seasonal Hydroclimate Change in the Sacramento river basin California, Physical Geography 1998, 19 (3), pp. 239-255.

10. You, Q. Jiang, H., Liu, Y., Liu, Z. Guan, Z. (2019). Probability Analysis and Control of River Runoffsediment Characteristics based on Pair-Copula Functions: The Case of the Weihe River and Jinghe River. Water 2019, 11 (3), pp. 510.

11. Lojen, S., Trkov, A., Ščančar, J., Vázquez-Navarro, J. A., Cukrov, N. Continuous 60-year stable isotopic and earth-alkali element records in a modern laminated tufa (Jaruga, river Krka, Croatia): Implications for climate reconstruction. Chemical Geology 2009, 258, pp. 242-250.

12. Bonacci, O. Andrić, I. Sinking karst rivers hydrology - case of the Lika and Gacka (Croatia). Acta Carsologica 2008, 37(2-3), pp. 185-196.

13. Tadić, L. Criteria for Evaluation of Agricultural Land Suitability for Irrigation in Osijek County Croatia. Problems, Perspectives, and Challenges of Agricultural water management. Kumar, M., InTech, Rijeka, Croatia, 2012, pp. 311-332.

14. Muhar, A. Doprinos analizi rada uređaja za pročišćavanje otpadnih voda s obzirom na pojedine pokazatelje kakvoće otpadne vode i na utjecaj oborina primjenom metode RAPS (Original on Croatian; Contribution to the analysis of the operation of wastewater treatment plants with regard to individual indicators of wastewater quality and the impact of precipitation using the RAPS method). Rector's Award, Varaždin/Zagreb, Croatia, 2017.

15. Ptiček Siročić, A., Đurin, B., Glumac, N., Nađ, L. Analiza odstupanja vrijednosti pokazatelja kakvoće otpadne vode pomoću RAPS metode (Original on Croatian; Variance analysis of quality indicators values of wastewater by RAPS method). Proceedings $7^{\text {th }}$ International Scientific and Professional Conference Water for all. Osijek, 2018, pp. 251-262.

16. Đurin, B., Ptiček Siročić, A., Muhar, A. Analiza povezanosti pokazatelja kakvoće otpadne vode s temperaturom i oborinama pomoću RAPS metode. Hrvatske vode 2017, 25 (102), pp. 247-252.

17. Marget, M. Analiza kakvoće otpadne vode na uređaju za pročišćavanje otpadnih voda primjenom metode RAPS (Original on Croatian; Wastewater quality analysis on the device for wastewater treatment using the RAPS method), Faculty of Geotechnical Engineering, University of Zagreb, Varaždin, Croatia, 2019.

(C) 2020 by the authors; licensee MDPI, Basel, Switzerland. This article is an open access article distributed under the terms and conditions of the Creative Commons by Attribution (CC-BY) license (http://creativecommons.org/licenses/by/4.0/). 